\title{
FORMAÇÃO PARTICIPADA DO MÉRITO PROCESSUAL E JURISDIÇÃO CONSTITUCIONAL: REVISITAÇÃO TEÓRICA DAS CONDIÇÕES DA AÇÃO SOB A ÓTICA DA PROCESSUALIDADE DEMOCRÁTICA.
}

\author{
PARTICIPATED PROCEDURAL MERIT FORMATION AND \\ CONSTITUTIONAL JURISDICTION: THEORETICAL REVISITATION OF \\ CONDITIONS OF ACTION FROM THE PERSPECTIVE OF DEMOCRATIC \\ PROCESSUALITY.
}

\author{
Fabrício Veiga Costa ${ }^{1}$ \\ Maurício Gomes Pereira França ${ }^{2}$
}

\begin{abstract}
SUMÁRIO: 1. Introdução. 2. Compreensão e distinções teóricas do mérito processual frente a institutos a ele correlatos. 3. O princípio da inafastabilidade da apreciação jurisdicional como corolário ao exercício da jurisdição constituição. 4. O processo enquanto instituição constitucionalizada no Estado Democrático de Direito. 5. Condições da ação como matéria de mérito. 6. A jurisdição constitucional como direito ao debate do mérito processual. 7. Conclusão. 8. Referências.
\end{abstract}

RESUMO: A dessacralização do instituto jurídico do mérito processual perpassa pela superação de concepções herméticas e dogmáticas. Para isso, torna-se necessário esclarecer que a ressignificação do mérito processual na perspectiva do processo individual decorre da necessidade de demonstrar-se que o respectivo instituto relaciona-se, mas não fica adstrito, à matéria de mérito (questões controvertidas que integram a pretensão deduzida em juízo). A releitura crítica do respectivo instituto permite esclarecer que, sob o ponto de vista da hermenêutica constitucional no Estado Democrático de Direito, mérito processual é o Direito Fundamental assegurado a todos os jurisdicionados e interessados no provimento de ampla discurssividade de todas as questões controvertidas que integram a pretensão inicialmente deduzida. A implementação dos princípios do contraditório, da ampla defesa e do devido processo legal são corolários necessários ao entendimento da legitimidade democrática dos provimentos jurisdicionais. Nesse ínterim, a jurisdição constitucional é o referencial teórico para repensar o mérito processual como esse Direito Fundamental assegurado a todos os jurisdicionados, não somente de discutir as questões controvertidas em juízo, mas, também, de obter um pronunciamento judicialmente fundamentado no direito, ressaltando-se como tais questões serão jurídico-constitucionalmente apreciadas pelo julgador. É nesse contexto que se torna relevante a abordagem teórico-pragmatica da relevância jurídica de as condições da ação passarem a integrar a matéria de mérito, uma vez que são questões controvertidas intrinsecamente relacionadas com a pretensão inicialmente deduzida em juízo.

Palavras-chave: Mérito Processual. Jurisdição Constitucional. Processualidade Democrática.

ABSTRACT: The demystification of the legal institute of merital procedure permeates the overcoming of dogmatic and hermetic concepts. Therefore, it is necessary to clarify that the procedural merits reframing, in individual procedure perspective, stems the need to demonstrate that this institute is related to, but is not attached, the merit (controversial issues that is part of the claim deducted in court). A critical reinterpretation of the respective institute allows to clarify that, from the hermeneutics in constitutional point of view in a Democratic rule of Law State, procedural merit is the fundamental right granted to all people under jurisdiction and people with interest in providing wide discursivity of all controversial issues that integrate the claim initially deducted. The implementation of the principles of contraditory, legal defense and due process of law are necessary corollaries to the understanding of democratic legitimacy of judicial sentences. Meanwhile, the constitutional jurisdiction is the theoretical framework to rethink the procedural merit as this fundamental right guaranteed to all people under jurisdiction, not only to discuss the issues disputed in court, but also to obtain a judicial pronouncement based on the law, emphasizing such as legal and constitutional issues will be considered by the judge. It is in this context that becomes relevant the theoretical and pragmatic approach to the legal significance of the conditions of action pass to integrate the merits, since they are inherently controversial issues related to the claim initially deducted in court.

Keyword: Merital Procedure. Constitutional Jurisdiction. Democratic Processuality.

\section{INTRODUÇÃO}

\footnotetext{
${ }^{1}$ Doutor, Mestre e Especialista em Direito Processual e Direito de Família pela Pucminas. Bacharel em Direito pela Universidade Federal de Uberlândia. Professor e Advogado em Belo Horizonte. Membro do Instituto dos Advogados de Minas Gerais e da Comissão de Ética e Disciplina da OAB/MG.

${ }^{2}$ Mestrando em Direito pela Universidade de Itaúna. Especialista em Direito Processual pela Pucminas. Bacharel em Direito pela Universidade de Itaúna. Advogado. Professor e Coordenador do Núcleo de Práticas Jurídicas da Faculdade de Pará de Minas - FAPAM.
} 
A problemática científica que integra o debate crítico do tema-problema objeto da presente pesquisa consiste no estudo do mérito processual como corolário do exercício da jurisdição constitucional no Estado Democrático de Direito.

Nessa seara, é importante esclarecer que a jurisdição constitucional é vista como um Direito Fundamental assegurado a todo jurisdicionado no que tange à formação participada do provimento final, considerada reflexo da ampla e discursiva análise das questões que integram a pretensão inicialmente deduzida em juízo.

Dessa forma, verifica-se que o entendimento teórico proposto na presente pesquisa não condiz com a ideológica concepção de que a jurisdição é uma atividade pessoal do julgador $^{3}$, o que legitimaria sua atuação no sentido de analisar unilateralmente as questões que integram o mérito processual.

É neste contexto que é possível delinear com maior exatidão a hipótese cientifica que direcionará todo o estudo a ser desenvolvido ao longo da pesquisa: considerando-se que a jurisdição é um Direito Fundamental (e não uma atividade pessoal do decididor), pretende-se esclarecer que a formação do provimento final deve ser reflexo do amplo debate das questões que integram o mérito e da participação direta dos interessados e afetados juridicamente pelos efeitos do provimento final.

A revisitação teórica das condições da ação, tal como propostas pelo legislador do Código de Processo Civil brasileiro vigente, é imprescindível para esclarecer que o instituto da extinção do processo sem análise do mérito por carência de ação não foi recepcionado pelo modelo de processo adotado pelo legislador constituinte, considerando-se que a legitimidade ad causam, o interesse de agir e a possibilidade jurídica do pedido integrariam as questões objeto do debate meritório no âmbito processual.

Não se pretende com a presente pesquisa demonstrar que o fenômeno processual da sentença terminativa não foi por inteiro recepcionado pela processualística constitucionalizada, tendo em vista que, as questões que não integram o mérito processual, tal como os pressupostos processuais, certamente são fundamentos coerentes para justificar a extinção do processo sem resolução do mérito.

A justificativa objetiva da escolha do tema-problema funda-se na proposta de discussão das condições da ação como matéria de mérito, e não mais como requisito imprescindível à resolução do mérito, tal como proposto pelo legislador do Código de Processo Civil.

O referencial teórico para compreender que as condições da ação passariam a integrar o mérito da pretensão deduzida em juízo encontra-se no entendimento críticosistemático do principio da inafastabilidade da apreciação jurisdicional (artigo $5^{\circ}$, inciso XXXV da Constituição brasileira de 1988).

A partir dessas premissas iniciais, é possível afirmar que o exercício da jurisdição constitucional realmente se efetiva quando há a extinção do processo sem resolução do mérito por carência de ação? Considerar as condições da ação como pressupostos lógicos de análise do mérito não seria legitimar a limitação do exercício do Direito Fundamental à Jurisdição Constitucional?

\footnotetext{
${ }^{3}$ Na lição positivista de GRINOVER, Ada Pellegrini; CINTRA, Antônio Carlos de Araújo; DINAMARCO, Cândido Rangel. inTeoria Geral do Processo, 21ed. São Paulo: Malheiros Editores, 2005, afirma-se que a jurisdição, enquanto atividade, corresponde ao "complexo de atos do juiz no processo, exercendo o poder e cumprindo a função que a lei lhe comete" p. 139. Por poder afirmam os autores tratar-se de poder de decidir imperativamente. Por função aduzem que é função estatal a pacificação social através da justa decisão oriunda do processo. Crê-se que tal visão destoa dos modelos de organização jurídico-político do Estado brasileiro (Estado Democrático de Direito) e, consequentemente do modelo de teoria do direito de que se vale para legitimar o firmamento de tal paradigma. Deflui-se, por raciocínio reflexo necessário, que a abordagem da jurisdição enquanto atividade pessoal do julgador inviabiliza o exercício do direito de ação pelos jurisdicionados, porquanto mantém a retrograda segregação entre Estado-Sociedade Civil.
} 
A análise peremptória e precipitada pelo julgador acerca das condições da ação contraria toda a processualidade democrática, tendo em vista que retira das partes o direito de amplo debate das questões que integram o mérito processual, tal como ocorre, por exemplo, com a legitimidade processual. Por isso, ressalta-se que a instrução e a dilação probatória são formas de legitimar democraticamente o provimento final, viabilizar a sua construção participada e, acima de tudo, aprofundar no estudo e na análise apurada de todas as questões que delimitam o objeto da demanda, algo que não ocorre quando o julgador deixa de resolver o mérito por concluir de forma sumária pela carência de ação.

Utilizando-se de pesquisa bibliográfica mediante consulta e análise de proposições teóricas apresentadas por estudiosos e pesquisadores que discutem direta ou indiretamente o tema em tela, passou-se à construção de análise sistemático-constitucionalizada com o fito de viabilizar o entendimento crítico de que a jurisdição constitucional, enquanto Direito Fundamental, é o referencial teórico para a resignificação das condições da ação não mais como requisito de análise do mérito, mas, sim, como parte integrante das questões inerentes ao mérito processual.

\section{COMPREENSÃO E DISTINÇÕES TEÓRICAS DO MÉRITO PROCESSUAL FRENTE A INSTITUTOS A ELE CORRELATOS}

Etimologicamente, a palavra mérito vem do latim para designar merecimento, aptidão, superioridade, bom serviço (BASTOS, 1928, p. 912). Processualmente, observa-se que a construção de toda a discussão sobre o que é o mérito no âmbito do processo civil é um tanto polissêmica, ideologicamente vinculada a um modelo de processo um particularmente autoritário, uma vez que "[...] o julgamento do mérito é uma prerrogativa inerente às pessoas que merecem discutir os fundamentos fático-jurídicos da pretensão deduzida em juízo por terem demonstrado previamente os requisitos legais que viabilizam a análise e a participação na discussão meritória" (COSTA, 2012, p. 08). Nesse modelo autocrático (não democrático) de processo, o decididor seria o sujeito dotado de um conhecimento pressuposto para merecer a legitimidade de discutir os fundamentos das questões controvertidas em juízo, mesmo que para isso venha a se utilizar de argumentos de cunho jurídico e metajuridico.

A indefinição teórica e conceitual é um aspecto que caracteriza o entendimento cientifico do instituto do mérito processual, ora visto como lide, pretensão, causa de pedir, demanda. Importante inicialmente esclarecer que, embora o mérito tenha relação com as questões controvertidas em juízo, a elas não se limitam. Considerando-se que a lide pode ser, na perspectiva Carnelluttiana, previamente definida como um conflito de interesses qualificado por uma pretensão resistida; que a pretensão é a narração reivindicativa de direitos materializados na petição inicial; que exordial é o instrumento gráfico-cartular materializador da pretensão; que pretensão é a expectativa assegurada às partes legitimadas quanto à proteção judicial de um determinado bem jurídico da vida; que a demanda é a definição das questões controvertidas que integram o objeto da lide, pode-se concluir que o mérito processual nada mais é do que um procedimento de ampla e constitucionalizada discursividade das questões controversas trazidas pelas partes e que integram a demanda judicial. Assim, ressalta-se que o mérito processual não pode ser visto meramente como as questões controversas propostas pelas partes mas, acima de tudo, como todas as controvérsias efetivamente debatidas pelas partes em juízo e que influenciarão diretamente na formação participada do provimento final.

Pelo estudo sistemático da doutrina, verifica-se certa falta de cuidado científico no sentido de esclarecer as distinções teóricas existentes entre os institutos acima correlatos. Ao longo do texto do Código de Processo Civil verifica-se o descuido por parte do legislador quanto à conceituação teórica sobre o mérito processual, ora o mencionando como lide, como 
pedido ou causa de pedir. "Esse foi o posicionamento adotado pela Exposição de Motivos do Código de Processo Civil ${ }^{4}$ brasileiro vigente, onde se verifica a utilização da palavra Lide para designar o mérito da causa" (COSTA, 2012, p. 11).

A polissemia jurídica e a indefinição jurídica sobre o entendimento mais adequado sobre o que é o mérito processual está evidenciada claramente ao longo do Código de Processo Civil brasileiro. No disposto no artigo 330 do Código de Processo Civil, verifica-se a vinculação do instituto do mérito processual às questões de fato e de direito que integram o objeto da pretensão inicialmente deduzida em juízo. Em contrapartida, sabe-se que o próprio artigo 486 do Código de Processo Civil brasileiro vigente vincula o conceito de mérito ao instituto da lide, entendimento esse corroborado pelo jurista mineiro José Marcos Vieira, que é categórico ao afirmar que "o mérito é o pedido e é a lide, ou, como visto, é esta nos limites daquele (VIEIRA, 2002, p. 160). Para Cândido Rangel Dinamarco "o mérito é o complexo de questões materiais que a lide apresenta" (1996, p. 200).

Para Giuseppe Chiovenda o mérito processual reside no conceito de demanda, ou seja, "é o ato pelo qual a parte, afirmando existente uma vontade concreta de lei, que lhe garante um bem, declara querer que essa vontade se atue, e invoca para esse fim a autoridade do órgão jurisdicional" (CHIOVENDA, 1969, p. 297).

O que se depreende dessas colocações iniciais é que mérito processual para o processo civil clássico nada mais é do que o objeto da lide, ou seja, julgar o mérito é o mesmo que permitir ao julgador, no momento em que profere o despacho saneador, elencar as questões por ele consideradas relevantes no que tange ao julgamento do que entende relevante para cada caso concreto. Tal concepção contraria diretamente a o modelo de processo adotado e proposto pela Constituição brasileira de 1988, tendo em vista que no momento em que o julgador ignora debater e apreciar uma ou mais questões trazidas pelas partes à relação processual ora instituída, certamente corroborará para limitar o exercício pleno do direito de ação e para o cerceamento de defesa.

A implementação do contraditório ${ }^{5}$, da ampla defesa e do devido processo legal condiciona-se ao direito que cada jurisdicionado e parte juridicamente interessada no provimento final têm de que todas as questões ora suscitadas e propostas em juízo serão pelo menos enfrentadas e analisadas pelo julgador em decisão jurídico-legalmente fundamentada, mesmo que uma ou mais alegações não venham a ser reconhecidas pelo juízo originariamente competente.

A análise sumária, peremptória e arbitrária pelo julgador quanto às condições da ação representa verdadeira afronta ao Direito Fundamental à Jurisdição (constitui verdadeira negativa de jurisdição), especificamente no que tange à supressão do direito das partes poderem debater critica e efetivamente as questões por elas levantadas e consideradas

\footnotetext{
${ }^{4}$ Demonstrando a promiscuidade do legislador na utilização da expressão, em caminho seguido por outros processualistas, Cândido Rangel Dinamarco mostrou que o legislador brasileiro, na Exposição de Motivos do Código de Processo Civil conferiu à palavra "lide", dentre outros, o significado de "mérito", o mesmo ocorrendo, quase sempre, ao longo do mencionado diploma legal. Assim, expressões como "julgamento antecipado da lide" (v.g. nomenclatura utilizada na seção em que se encontra o artigo 330), "julgar total ou parcialmente a lide" (artigo 46, inciso I), "conhecimento da lide" (artigo 110) e outras tantas são exemplos da utilização da palavra lide como sinônimo de mérito (MADEIRA, 2010, p. 109).
}

${ }^{5}$ [...] o principio do contraditório é referente lógico-jurídico do processo constitucionalizado, traduzindo-se, em seus conteúdos, a dialogicidade necessária entre interlocutores (partes) que postam em defesa ou disputa de direitos alegados, podendo, até mesmo, exercer a liberdade de nada dizerem (silêncio), embora tendo direitogarantia de se manifestarem. Daí, o direito ao contraditório ter seus fundamentos na liberdade jurídica tecnicamente exaurida de contradizer, que, limitada pelo tempo finito (prazo) da lei, converte-se em ônus processual se não exercida. Conclui-se que o processo, ausente o contraditório perderia sua base democráticojurídico-principiológica e se tornaria um meio procedimental inquisitório em que o arbítrio do julgador seria a medida colonizadora da liberdade das partes (LEAL, 2009, p. 97). 
relevantes ao julgamento do mérito processual. Considerando-se a jurisdição como um Direito Fundamental, a escusa do magistrado em reconhecer o direito de debate das questões controvertidas que integram o mérito processual, de modo a não permitir a cada jurisdicionado o direito de influir diretamente na construção do provimento final, certamente caracteriza expressa violação do Direito de Acesso à Jurisdição Democrática. Nesse sentido, se posiciona Ronaldo Bretas de Carvalho Dias

[...] há de se destacar que a função jurisdicional, no Estado Democrático de Direito, não é atividade beneficente, obsequiosa ou caritativa, mas atividadedever do Estado, razão pela qual, em contrapartida, é direito fundamental de qualquer um do povo (governantes e governados) e também dos próprios órgãos estatais obtê-la, a tempo e modo, vale dizer, de forma adequada e eficiente, pela garantia do devido processo constitucional (DIAS, 2010, p. 47).

A extinção do processo sem julgamento do mérito por carência de ação nada mais é do que a materialização do cerceamento de defesa no momento em que o decididor, de forma unilateral, seleciona via despacho saneador quais serão as questões controversas por ele consideradas relevantes, desconsiderando-se, na maioria das vezes, toda a legitimidade das partes ampliarem o debate e participarem diretamente da construção do provimento final. Nesse sentido ressalta-se que "a extinção do processo sem julgamento do mérito por carência de ação deve ser vista como um meio ilegítimo de exclusão das partes na construção participada do mérito processual (COSTA, 2012, p. 13).

É de suma importância esclarecer que no Estado Democrático de Direito a jurisdição deve ser vista e compreendida teoricamente como um Direito Fundamental assegurado a todas as pessoas físicas e jurídicas, exercida pelo direito de petição, pautada no principio da soberania popular, o que assegura a todo jurisdicionado o direito de participar diretamente da construção do provimento final ${ }^{6}$. Nesse contexto, o mérito processual não pode ser visto como uma mera consequência de conjecturas unipessoais do julgador, de levar em consideração sumariamente apenas aquelas questões por ele vistas como relevantes no julgamento da pretensão inicialmente deduzida em juízo.

\section{O PRINCIPIO DA INAFASTABILIDADE DA APRECIAÇÃO JURISDICIONAL COMO COROLÁRIO AO EXERCÍCIO DA JURISDIÇÃO CONSTITUCIONAL}

Importante que a análise da inafastabilidade da apreciação jurisdicional se dê a partir do enfoque do Estado Democrático de Direito - modelo jurídico-político adotado pela Constituição brasileira de 1988 - com o escopo de se alcançar a verdadeira dimensão de tal princípio-garantia fundamental.

Constitui Direito Fundamental corolário ao exercício da cidadania o direito à apreciação jurisdicional. A partir dessa proposição teórica, levanta-se a seguinte hipótese cientifica: como essa apreciação jurisdicional é realizada? Quão legítima é a decisão, se considerada a partir da necessária e efetiva participação dos interessados no contexto do Estado Democrático de Direito?O direito de apreciação jurisdicional materializa-se democraticamente a partir do direito que as partes interessadas têm de debater as questões

\footnotetext{
${ }^{6}[\ldots]$ no Estado Democrático de Direito, a jurisdição é direito fundamental das pessoas naturais e jurídicas, sejam estas de direito público ou de direito privado, porque positivado ou expresso no texto da Constituição Federal de 1988 (art. $5^{\circ}$, inciso XXXV). Exatamente por isto, se é direito fundamental do povo, em contrapartida, é atividade-dever do Estado, prestada pelos seus órgãos competentes, indicados no texto da própria Constituição, somente possível de ser exercida sob petição daquele que a invoca (direito de ação) e mediante a indispensável garantia fundamental do devido processo constitucional (art. $5^{\circ}$, incisos LIII, LIV e LV) (DIAS, 2010, p. 75).
} 
controvertidas que integram o mérito processual? As condições da podem ser compreendidas criticamente como questões controversas que integram a matéria de mérito?

É a partir de tais indagações que se pretende desenvolver a análise da relação existente entre a jurisdição constitucional, o mérito processual e a revisitação teórica das condições da ação como matéria de mérito (não mais como pressuposto de análise das questões meritórias).

Desafortunadamente ainda remanesce a interpretação de um acesso à justiça na concepção do Estado Liberal clássico, para o qual o exercício do direito de ação detinha-se como mera forma de provocar a jurisdição e aguardar que esta fornecesse aos interessados no provimento uma decisão redentora. Não se preocupava com a forma como tal manifestação jurisdicional seria elaborada. Bastava tão-somente a existência do pronunciamento unilateral e soberano do decididor.

O caráter polissêmico e a significação metajurídica da expressão acesso à justiça é utilizado para fundamentar teoricamente a concepção atinente à visão de que a jurisdição é uma atividade pessoal do julgador, legitimado a decidir de forma justa, podendo, assim, criar o direito mais adequado ao caso concreto, afastar-se da lei, se considerá-la injusta e decidir a partir dos cognominados juízos peremptórios e autocráticos que permeiam a equidade.

Quando da formação desse Estado Liberal clássico (século XVIII), o direito de ação era parte que integrava o direito material pretendido e por tal razão não poderia ser elevada à condição de direito fundamental.

Calha aqui realizar brevíssima digressão histórica com o fito de demonstrar a emancipação do direito de ação enquanto direito concreto para que então promover a abordagem evolucionária (não autopoiética) do direito de ação corolário do exercício da jurisdição constitucionalizada pela construção participada do provimento.

Os debates acadêmicos travados entre Windscheid e Müther foram determinantes para o rompimento da ideia da ação como um direito umbilicalmente ligado ao direito material (COSTA, 2012, p. 25).

Anteriormente à ruptura, a ação era imanente ao direito material objeto da discussão. Havia, assim, a compreensão de que a ação seria, em verdade, uma espécie de reação à afronta de um direito material (PAIXAO JUNIOR, 2002, p. 83). O autor cita Clovis Belvilaqua ao explicar a ação como reação: “...a ação é parte constitutiva do direito subjetivo, pois que é o próprio direito em atitude defensiva. Neste sentido, ação corresponde ao Anspruch do direito alemão".

A partir do dogma da ação como reação à afronta a um direito material, revelavam-se "três consequências inevitáveis: não há ação sem direito; não há direito sem ação; a ação segue a natureza do direito" (CINTRA, 1991, p. 258).

O próprio direito positivo brasileiro sofreu influência dessa noção privatística da ação. O artigo 75 do Código Civil de 1916 ditava que "a todo direito corresponde uma ação que o assegura". As discussões travadas entre Windscheid e Muther renderam frutos. A ação desligou-se do direito material, sob o aspecto da dependência, e ganhou contornos de autonomia. Na lição de Humberto Theodoro Júnior a

célebre polêmica entre os renomados romanistas Windscheid e Muther acabou por demonstrar que são realidades distintas o direito lesado e a ação, pois esta cria, a par do direito subjetivo material da parte prejudicada, dois outros direitos públicos: a) um, para o ofendido, que é o direito à tutela jurisdicional, e que é dirigido contra o Estado; e b) outro, para o próprio Estado, que é o direito de eliminar a lesão jurídica e que se volta contra a parte que a causou (THEODORO JR. 2009, p. 57). 
Consigne-se que os direitos fundamentais na época do Estado Liberal Clássico eram direitos que versavam acerca de liberdades e defesas. Uma forma de frear ou obstaculizar a intervenção estatal. Não se vislumbravam, naquela época, direitos fundamentais como direitos a prestações, ações positivas.

A inafastabilidade da apreciação jurisdicional, partir do corte direito de ação e à análise do mérito construído de forma participada, deve ser considerada como uma garantia constitucional corolário à efetivação do acesso efetivo ao Judiciário. A garantia de todas as garantias na medida em que, frente a qualquer afronta ou iminência de arrepio de um direito, fundamental ou não, será o direito de ação o fio condutor para exigir do Estado a providência pertinente.

Ocorre que o enfoque destinado à real garantia do direito fundamental em questão é o enfoque da análise aprofundada e comprometida acerca dos apontamentos dos interessados no provimento final. Não se pode conceber que o direito à apreciação jurisdicional seja visto como um ato de benesse, a partir das percepçõesdo decididor.

No paradigma do Estado Democrático o provimento somente se legitima se proferido a partir de bases constitucionalizadas do processo quando da atuação jurisdição. Esta não deve ser entendida como exercício realizado a partir de ações mediônicas ou metafísicas, mas a partir do fruto do diálogo participativo e transformador dos interessados no resultado do processo.

Nesse contexto do debate do tema-problema ora proposto, está evidente que o fundamento teórico balizador para legitimar o exercício pleno da jurisdição constitucional democrática encontra-se no princípio da inafastabilidade da apreciação jurisdicional, cuja materialização dar-se-á mediante o direito de amplo debate do mérito processual pelos sujeitos interessados no provimento final, considerando-se todos àqueles realmente afetados pelos efeitos jurídicos do ato processual de cunho decisório.

O legislador constituinte ao institucionalizar o direito de amplo acesso ao Judiciário pretendeu superar o entendimento autocrático de uma jurisdição salvadora e materializada no poder do julgador, assim como buscou esclarecer que o exercício do direito de ação não fica adstrito às condições da ação, uma vez que as mesmas constituem óbice à apreciação da lesão e da ameaça a direitos. O acesso democrático ao Judiciário, como coextensão da jurisdição constitucional, é pressuposto para o exercício processualizado da cidadania, considerada o direito de participação no processo, ou seja, na construção e no debate das questões controversas que integram o mérito processual ${ }^{7}$.

A legitimidade democrático-constitucionalizada da construção do mérito processual pelos interessados no provimento pressupõe a observância do principio do contraditório, considerado o fundamento essencial para o exercício do direito de ação a partir da oportunização isonômica de debate das questões controvertidas, cabendo ao julgador a análise e apreciação jurídica de tudo o que foi trazido aos autos pelas partes.

\footnotetext{
${ }^{7}$ A compreensão da ideologia do acesso à justiça não pode se limitar ao entendimento atinente ao direito de estar em juízo, ao direito de reconhecimento jurídico da pretensão ou ao direito a uma prestação jurisdicional em que o juiz poderá ou não enfrentar o mérito da pretensão deduzida. É preciso reconstruir o entendimento clássico, dogmático e positivista do acesso à justiça, como o direito a uma ordem jurídica justa, cuja justiça se efetiva a partir da visão unilateral do juiz acerca do caso concreto. A revisitação dessa concepção filosófica de justiça decorrente do poder jurisdicional e da autoridade do juiz se faz necessária para a resignificação do entendimento do tema a partir de proposições teóricas decorrentes de um direito construído em bases democráticas. $\mathrm{O}$ acesso ao Judiciário deve ser visto como um Direito Fundamental de participação efetiva no debate jurídico construído em bases processuais em que os sujeitos juridicamente interessados sintam-se coautores do provimento. Nesse ínterim, sabe-se que a compreensão do acesso à justiça como um Direito Fundamental é o fundamento teórico para viabilizar a cidadania como pilar da participação dos interessados no processo (COSTA, 2012, p. 75-76).
} 


\section{O PROCESSO ENQUANTO INSTITUIÇÃO CONSTITUCIONALIZADA NO ESTADO DEMOCRÁTICO DE DIREITO}

A Constituição brasileira de 1988, ao instituir o Estado Democrático de Direito, trouxe a baila proposições teóricas suficientes à superação da concepção jurídica, ideológica e dogmática de que o processo é mero instrumento para o exercício da jurisdição. A Teoria Neo-institucionalista do Processo ${ }^{8}$, de autoria do jurista mineiro Rosemiro Pereira Leal, propõe "os estudos do processo como instituição constitucionalizada apta a reger, em contraditório, ampla defesa e isonomia, o procedimento, como direito-garantia fundamental" (LEAL, 2009, p. 84).

Nessa seara pode-se afirmar que o processo enquanto instituição constitucionalizada é considerado um espaço de ampla discursividade fática e jurídico-constitucional de todas as questões controvertidas que integram a matéria de mérito. "Infere-se que uma teoria neoinstitucionalista do processo só é compreensível por uma teoria constitucional de direito democrático de bases legitimantes na cidadania (soberania popular) (LEAL, 2009, p. 86).

Os princípios institutivos do processo representam o referencial jurídicoconstitucional-democrático e a base legitimante dos provimentos estatais, que deixam de ser produto de meras conjecturas decorrentes da sapiência inata dos julgadores, passando a ser reflexo de amplo debate da pretensão deduzida pelas partes juridicamente interessadas e legitimadas a participar de forma efetiva do debate das questões controversas.

O contraditório é o principio que institucionaliza e legitima a dialogicidade da pretensão pelos sujeitos juridicamente interessados no provimento e, ao mesmo tempo, é utilizado como parâmetro para estabelecer critérios objetivos (não subjetivos) ao julgador no ato de decidir. Considerada uma coextensão do contraditório, a ampla defesa é um principio que estabelece limites temporais do procedimento em contraditório (LEAL, 2009, p. 98). O jurista mineiro Dierle José Coelho Nunes é pontual ao afirmar que "a leitura do contraditório como garantia de influência no desenvolvimento e resultado do processo" (NUNES, 2008, p. 227), colocação essa necessária para justificar a abordagem critica do tema-problema proposto. Trata-se do direito que toda parte interessada tem de não ser surpreendida por uma decisão sumária e unilateralmente elaborada pelo julgador. A observância e a efetivação dos princípios do contraditório e da ampla defesa não decorrem da mera oportunização das partes apresentarem suas alegações, mas, acima de tudo, do direito-garantia assegurado às partes de que suas alegações de cunho fático e jurídico acerca da matéria de mérito serão apreciadas e analisadas objetivamente pelo julgador em decisão fundamentada.

A finalidade precípua do modelo constitucional de processo é proporcionar aos interessados no provimento o direito de ampla argumentação das provas, das questões controversas e da real possibilidade das partes conseguirem influir diretamente na formação do mérito processual e do provimento final.

A supremacia das normas constitucionais sobre as normas processuais de cunho infraconstitucional; a igualdade de oportunidade de argumentação jurídica da pretensão pelas partes interessadas; o direito de amplo acesso ao Judiciário, materializado pela efetiva oportunidade de discussão das questões controversas que integram a matéria de mérito; o principio da soberania popular, corolário do exercício processualizado da cidadania a partir da

\footnotetext{
${ }^{8}$ Nessa perspectiva, a teoria neo-institucionalista, enfrentando as aporias do conhecimento e o projeto de reinstitucionalização da democracia e da Constituição em bases processuais, propugna que os direitos fundamentais da vida, da liberdade e dignidade são direitos já discutidos e acertados no plano do processo instituinte (devido processo constitucional) somente possíveis de serem alterados pelo devido processo legislativo e que a isonomia, a ampla defesa e o contraditório são direitos fundantes, ou seja, possibilitadores do discurso incessante, não passíveis de alteração, senão se engessa o sistema com expurgo do paradigma democrático (ALMEIDA, 2005, p. 132-133).
} 
ampla discursividade das questões que integram o mérito processual; o direito a um processo sem dilações indevidas (duração razoável do processo e lealdade processual); a obrigatoriedade de fundamentação jurídico-constitucional de todos os atos processuais, assim como o direito das partes participarem diretamente da formação do provimento final são consideradas as vigas mestras de toda a teoria do processo constitucional democrático.

São esses os argumentos utilizados como patamar para a ressemantização da concepção clássica e autocrática do modelo de processo proposto pelo legislador do Código de Processo Civil brasileiro vigente, absolutamente centrado na autoridade do decididor e fundado na ampla liberdade de interpretar, criar e valorar o direito a ser aplicado ao caso concreto.

O modelo constitucional de processo é o contraponto teórico-pragmático para o enfrentamento crítico da concepção de processo vigente, ainda estagnada na ideologização de que a jurisdição é vista como uma atividade pessoal e sacerdotal do julgador, legitimando-o a julgar e a decidir em bases axiologizantes utilizadas para mascarar a pseudo-fundamentação jurídica decorrente da Hermenêutica Clássica e positivista.

O entendimento da processualidade democrática se justifica no contexto do temaproblema ora posto em debate em razão, inicialmente, da compreensão de que a jurisdição constitucional é o direito-garantia assegurado aos interessados de que não terão suas pretensões sumariamente julgadas e que poderão influir diretamente na construção do argumento jurídico mais adequado e pertinente às questões controversas que integram a matéria de mérito. Isso implica em revisitar as condições da ação, que passam a ser vistas como questões de mérito e, não mais, como pressuposto lógico para a análise do mérito processual.

Reconhecer que uma parte é ilegítima para integrar a relação processual, que inexiste interesse de agir ou que o pedido é juridicamente impossível, são questões que merecem uma análise mais detalhada e apurada no âmbito processual, ou seja, não pode ser uma avaliação sumária e peremptória realizada de forma unilateral pelo julgador. $\mathrm{O}$ amadurecimento da discussão dessas questões controversas que integram a matéria de mérito ocorrerá quando for ampliado o debate da pretensão inicialmente deduzida, viabilizando a participação das partes juridicamente interessadas.

Afirmar, por exemplo, que a parte autora é ilegítima para integrar uma determinada relação processual é o mesmo que reconhecer a inexistência de qualquer relação jurídico-legal entre demandante e demandado suficiente a justificar a viabilidade fática e jurídica da pretensão deduzida.

No momento em que o magistrado afirma inexistir interesse de agir reconhecerá a falta de legitimidade de o Judiciário intervir na análise da pretensão deduzida, questão essa que deve ser cuidadosamente analisada por ter relação direta com o principio da separação das funções estatais, considerado o critério norteador para a apreciação dessa matéria que integra o mérito da pretensão deduzida em juízo.

Reconhecer que um pedido é jurídica ou faticamente impossível demanda um estudo detalhado das principais questões controversas que integram a matéria de mérito.

É por isso que no contexto da processualidade democrática e da jurisdição constitucional o magistrado jamais poderá analisar as condições da ação no âmbito da cognição superficial, uma vez que tais questões integram o mérito da pretensão deduzida, de modo a exigir que o jurisdicionado participe da construção do provimento meritório a fim de assegurar a sua legitimidade democrática.

\section{CONDIÇÕES DA AÇÃO COMO MATÉRIA DE MÉRITO}


No início do século XX o processualista italiano Giuseppe Chiovenda sistematizou sua teoria da ação como um direito potestativo a partir da observância das condições da ação como requisitos imprescindíveis à análise do mérito da pretensão deduzida. Tal entendimento teórico foi recepcionado pelas obras de Carnelutti, Liebman e Alfredo Buzaid e, consequentemente, abarcado pelo Código de Processo Civil brasileiro de 1973 (COSTA, 2012, p. 75).

Assim, a possibilidade jurídica do pedido, a legitimidade processual e o interesse de agir passam a ser vistos e considerados como matérias extrínsecas ao mérito processual, uma vez que são condicionantes à sua análise processual.

Dessa forma, a ação, tal como preconizada pela legislação processual civil vigente, é juridicamente considerado um direito condicionado à demonstração prévia das condições da ação, uma vez que a ausência de qualquer delas impossibilitará a resolução do mérito da pretensão deduzida. A carência de ação, tal como abordada pela grande maioria dos estudiosos do processo civil, é vista como o arcabouço das sentenças terminativas.

Tal previsão legislativa legitima o julgador a analisar preliminarmente, de forma superficial e sumária, se todas as condições da ação estão presentes para, então, viabilizar a constituição válida da relação processual com a consequente análise das questões de mérito.

$\mathrm{Na}$ maioria das vezes, a respectiva análise préviaocasiona ao jurisdicionado o cerceamento de defesa, uma vez que se encontra impossibilitado de demonstrar, discutir e esclarecer ao juízo competente que todas as condições da ação estão presentes. A violação dos princípios do contraditório e da ampla defesa ocorre em virtude da necessidade de muitas vezes ter que adentrar à análise das questões de mérito como forma de demonstrar estarem presentes todas as condições da ação.

É por isso que na presente pesquisa propõe-se a releitura das condições da ação como matéria de mérito, uma vez que a visualização de sua existência no âmbito processual necessita, quase sempre, da oportunização da cognição exauriente, não meramente superficial.

A compreensão de que a parte não é legitima para integrar uma determinada relação processual condiciona-se à comprovação de que inexiste qualquer relação entre demandante e demandado hábil a justificar a viabilidade jurídica da pretensão deduzida.

A demonstração da necessidade e da utilidade de intervenção do Judiciário na análise da pretensão deduzida, assim como o esclarecimento da adequação da pretensão deduzida ao procedimento estabelecido na norma jurídica são questões que muitas vezes demandam uma análise mais apurada com o fim de auferir se efetivamente as partes possuem interesse de agir.

A auferição da pertinência e da viabilidade fático-jurídico-legal dos pedidos que delimitam o objeto da demanda efetivamente são questões que integram o mérito processual e, por isso, merecem um entendimento e uma análise sistematizados no âmbito da instrução processual. Permitir que o magistrado realize o juízo prévio de que a pretensão é juridicamente inviável é o mesmo que negar o acesso à jurisdição no que atine ao impedimento de discursividade pelas partes de toda a matéria de mérito.

É justamente nesse contexto teórico que se pretende demonstrar que a releitura crítica das condições da ação como matéria de mérito é a forma democrática mais legitima de viabilizar a implementação da jurisdição constitucional através da ampliação do que hoje se entende como matéria de mérito.

Ao reconhecer que as condições da ação integram as questões controvertidas da demanda, pode-se afirmar que há maior amplitude no debate jurídico pelas partes no âmbito processual, oportunizando, assim, a plena efetivação dos princípios do contraditório e da ampla defesa. Dessa forma, a jurisdição deixa de ser vista como mera prerrogativa ou poder pessoal do julgador decidir sumariamente pela não resolução do mérito por carência de ação 
para, então, ser compreendida sistematicamente como o direito assegurado a toda parte interessada de integrar o debate processualizado da pretensão inicialmente deduzida em juízo.

\section{A JURISDIÇÃO CONSTITUCIONAL COMO DIREITO AO DEBATE DO MÉRITO PROCESSUAL}

Conforme discutido anteriormente, verifica-se que a jurisdição constitucional democrática deve ser compreendida sistematicamente como um Direito Fundamental corolário do exercício da cidadania na perspectiva processual. Superar o dogma da jurisdição salvadora, produto da sabedoria inata do julgador, é pressuposto para o entendimento do tema problema proposto. $\mathrm{O}$ exercício da cidadania na perspectiva processualizada ocorre mediante a oportunização do direito de amplo debate de todas as questões meritórias pelas partes interessadas no provimento.

Nesse contexto, pode-se afirmar que o mérito processual não deve ser reflexo de uma cognição que se exterioriza em atos de inteligência inata e lógica do juiz. Na perspectiva da processualidade democrática, a atividade cognitiva do juiz "efetiva-se no momento em que o mesmo se imiscui no conflito de interesses propriamente dito, mediante a análise das questões de fato e de direito que integram a matéria de mérito da pretensão" (COSTA, 2012, p. 83).

Ao considerar as condições da ação como parte integrante da matéria de mérito temse ampliação de todo o debate democrático da pretensão deduzida, ou seja, estendem-se as questões controversas que integram a matéria de mérito ocasionando, por conseguinte, o exercício mais efetivo do contraditório, da ampla defesa e maior legitimidade democrática ao provimento.

Deve-se superar o entendimento teórico de que a cognição é um lócus de prevalência da subjetividade do julgador no ato de decidir através da implementação de argumentos de ordem axiológica e de equidade. No Estado Democrático de Direito a obrigatoriedade de fundamentação das decisões judiciais abre espaço para a superação do Movimento do Direito Livre como ideologia regente da concepção autocrática de jurisdição como atividade pessoal do decididor. Nesse sentido se posiciona o jurista mineiro Rosemiro Pereira Leal:

A persuasão do juiz no Estado Democrático de Direito, é construída pelos critérios que a lei estabelece para seu autoconvencimento ante os fatos e atos examinados. O julgador não pode decidir, assumindo o papel paternanista ou do magister em juízos de desvinculada subjetividade. O juiz não pode, portanto, decidir em face de um lei vazia à qual possa emprestar conteúdos de pessoal sabedoria, clarividência e magnanimidade (LEAL, 2009, p. 123).

O debate da matéria de mérito não deve ser concentrado na pessoa do juiz. O mérito processual não pode mais ser visto e compreendido como àquelas questões controversas consideradas relevantes pelo julgador quando da análise das peculiaridades fáticas e jurídicolegais que integram a pretensão deduzida. A processualização constitucionalizada e democrática acerca do mérito remete ao entendimento através do qual do respectivo instituto defluirá a legitimidade do provimento jurisdicional.

A decisão de mérito não pode ser produto de um debate limitado, restrito e concentrado das questões controversas especificamente definidas pelo juiz. Ao contrário disso, o que a presente pesquisa demonstrou foiinicialmente a relevância jurídica de ampliar a matéria de mérito com o escopo de incluir nesse contexto as condições da ação como parte integrante do mérito processual. Sabe-se que a jurisdição constitucional deve ser lida e interpretada como o Direito Fundamental de amplo debate critico, sistemático e constitucionalizado de todas as questões controversas que integram o mérito processual pelos interessados no provimento. 


\section{CONCLUSÃO}

Pensar criticamente o processo civil sob a égide da constitucionalidade democrática é saber que a jurisdição não é mera consequência da atuação pessoal do julgador, mas, sim, um Direito Fundamental de discursividade da pretensão assegurado a todo jurisdicionado.

A cognição exauriente se materializa pelo direito de debate amplo de todas as questões que integram a matéria de mérito, ressaltando-se que a definição das respectivas questões meritórias deve ser produto do amadurecimento da dialogicidade pelos interessados, bem como da obrigatoriedade do julgador analisar e se posicionar juridicamente sobre tudo o que foi alegado pelas partes nos autos.

Reconhecer jus-filosoficamente que as condições da ação integram a matéria de mérito é a forma de alcançar a legitimidade democrática do ato decisório pela ampliação das questões a serem apresentadas e discutidas pelas partes em juízo. Além disso, sabe-se que é uma forma de evitar o cerceamento de defesa decorrente do julgamento sumário de tais questões.

Não se pretende afirmar que o instituto da sentença terminativa deixou de existir no processo civil brasileiro, até porque, a ausência de pressupostos processuais de validade e de existência são critérios jurídico-legais hábeis a ensejar o não julgamento do mérito processual, haja vista que não constituem matéria de mérito, tal como ocorre com as condições da ação.

Em contrapartida, defende-se que a não apreciação do mérito pela carência de ação é algo que contradiz toda a sistematicidade jurídico-constitucionalizada do modelo de processo e de jurisdição propostos pelo Estado Democrático de Direito, uma vez que perpetuar o entendimento cientifico de que as condições da ação representam pressupostos lógicos para a análise da matéria de mérito, é o mesmo que admitir e legitimar a violação dos princípios do contraditório e da ampla defesa em razão da limitação do espectro da discursividade da pretensão deduzida pelas partes interessadas no provimento.

Dessa forma, afirma-se que o mérito processual deve ser visto como um procedimento materializador da dialogicidade da pretensão por todos os interessados juridicamente na pretensão e uma forma democrática de assegurar a legitimidade dos atos decisórios.

\section{REFERÊNCIAS}

ALMEIDA, Andréa Alves de. Processualidade Juridica e Legitimidade Normativa. Belo Horizonte: Fórum, 2005.

BASTOS, José Timóteo da Silva. Diccionário Etymológico, Prosódico e Orthográphico da Língua Portuguesa. São Paulo, 1928.

CHIOVENDA, Giuseppe. Instituições de Direito Processual Civil. Tradução de J. Guimarães Menegale. 3. ed. São Paulo: Saraiva, 1969.

CINTRA, Antônio Carlos de Araújo; GRINOVER, Ada Pelegrini; DINAMARCO, Cândido Rangel. Teoria Geral do Processo. 8. ed. São Paulo: Revista dos Tribunais, 1991.

COSTA, Fabrício Veiga. Mérito Processual - a formação participada nas ações coletivas. Belo Horizonte: Arraes Editores, 2012. 
DIAS, Ronaldo Bretas de Carvalho. Processo Constitucional. Belo Horizonte: Del Rey, 2010.

DINAMARCO, Cândido Rangel. A instrumentalidade do processo. 5. ed. São Paulo: Malheiros, 1996.

LEAL, Rosemiro Pereira. Teoria Geral do Processo - Primeiros Estudos. 8. Ed. Rio de Janeiro: Forense, 2009.

MADEIRA, Dhenis Cruz. Reflexões Propedêuticas sobre o mérito no processo civil. In: CASTRO, João Antônio Lima; FREITAS, Sérgio Henrique Zandona (Coord.) Direito Processual Reflexões Juridicas. Belo Horizonte: PUC Minas, Instituto de Educação Continuada, 2010, p.108-118.

NUNES, Dierle José Coelho. Processo jurisdicional democrático. Curitiba: Juruá, 2008. PAIXÃO JR., Manuel Galdino da. Teoria Geral do Processo. Belo Horizonte: Del Rey Editora, 2002.

THEODORO JUNIOR, Humberto. Curso de Direito Processual Civil. Teoria Geral do Direito Processual Civil e Processo de Conhecimento. V I, 50 ed. Rio de Janeiro: Editora Forense, 2009.

VIEIRA, José Marcos Rodrigues. Da Ação Cível. Belo Horizonte: Del Rey, 2002. 